\title{
Transport of Antarctic stratospheric strongly dehydrated air into the troposphere observed during the HALO-ESMVal campaign 2012
}

\author{
C. Rolf ${ }^{1}$, A. Afchine ${ }^{1}$, H. Bozem ${ }^{2}$, B. Buchholz ${ }^{3}$, V. Ebert $^{3}$, T. Guggenmoser ${ }^{1, a}$, P. Hoor ${ }^{2}$, P. Konopka ${ }^{1}$, E. Kretschmer ${ }^{4}$, \\ S. Müller ${ }^{2}$, H. Schlager ${ }^{5}$, N. Spelten ${ }^{1}$, O. Sumińska-Ebersoldt ${ }^{4}$, J. Ungermann ${ }^{1}$, A. Zahn $^{4}$, and M. Krämer ${ }^{1}$ \\ ${ }^{1}$ Forschungszentrum Jülich, IEK-7, 52457 Jülich, Germany \\ ${ }^{2}$ Institute for Atmospheric Physics, Johannes Gutenberg University of Mainz, 55122 Mainz, Germany \\ ${ }^{3}$ Physikalisch-Technische Bundesanstalt (PTB), 38116 Braunschweig, Germany \\ ${ }^{4}$ Karlsruher Institut für Technologie (KIT), IMK-ASF, 76021 Karlsruhe, Germany \\ ${ }^{5}$ Deutsches Zentrum für Luft und Raumfahrt, IPA, 82234 Oberpfaffenhofen, Germany \\ ${ }^{a}$ now at: European Space Agency, Noordwijk, the Netherlands \\ Correspondence to: C. Rolf (c.rolf@fz-juelich.de)
}

Received: 13 February 2015 - Published in Atmos. Chem. Phys. Discuss.: 16 March 2015

Revised: 8 July 2015 - Accepted: 27 July 2015 - Published: 18 August 2015

\begin{abstract}
Dehydration in the Antarctic winter stratosphere is a well-known phenomenon that is annually observed by satellites and occasionally observed by balloon-borne measurements. However, in situ measurements of dehydrated air masses in the Antarctic vortex are very rare. Here, we present detailed observations with the in situ and GLORIA remote sensing instrument payload aboard the German aircraft HALO. Strongly dehydrated air masses down to $1.6 \mathrm{ppmv}$ of water vapor were observed as far north as $47^{\circ} \mathrm{S}$ in an altitude between 12 and $13 \mathrm{~km}$ in the lowermost stratosphere. The dehydration can be traced back to individual ice formation events above the Antarctic Peninsula and Plateau, where ice crystals sedimented out and water vapor was irreversibly removed. Within these dehydrated stratospheric air masses, filaments of moister air reaching down to the tropopause are detected with the high-resolution limb sounder, GLORIA. Furthermore, dehydrated air masses are observed with GLORIA in the Antarctic lowermost stratosphere down to $7 \mathrm{~km}$. With the help of a backward trajectory analysis, a midlatitude origin of the moist filaments in the vortex can be identified, while the dry air masses down to $7 \mathrm{~km}$ have stratospheric origins. Antarctic stratospheretroposphere exchange (STE) and transport of dehydrated air masses into the troposphere are investigated. Further, it is shown that the exchange process can be attributed to several successive Rossby wave events in combination with an isentropic exchange of air masses across the thermal tropopause.
\end{abstract}

The transport into the troposphere is caused by air masses that are detached from the potential vorticity (PV) structure by Rossby wave breaking events and subsequently transported diabatically across the dynamical tropopause. Once transported to the troposphere, air masses with stratospheric origin can reach near-surface levels within several days.

\section{Introduction}

Antarctic stratospheric dehydration occurs regularly every winter and spring in the very isolated and very cold southern hemispheric polar vortex (e.g., Kelly et al., 1989; Schoeberl et al., 1992; Vömel et al., 1995; Nedoluha et al., 2002; Jimenez et al., 2006). The reason is that the temperatures in the Antarctic stratosphere are regularly sufficiently low for ice particles to form. These ice particles will sediment at a rate of $2.5 \mathrm{~km} \mathrm{~d}^{-1}$ depending on their size and will thus transport water to lower altitudes. If dehydration extends down to the tropopause, water is removed from the stratosphere and changes the stratospheric water vapor budget of the lower Antarctic vortex drastically. After the break-up of the Antarctic vortex, redistribution and exchange between vortex air and air masses outside the vortex lead to a return to typical stratospheric background water vapor mixing ratios of about 4-5 ppmv (Nedoluha et al., 2007). Rehydration with redistribution of water from the solid phase into the gas phase 
occurs at lower altitudes where ice crystals sublimate caused by subsaturation of water vapor at higher temperatures. In the Arctic region, stratospheric dehydration is also possible but much less frequent than in the Southern Hemisphere (e.g., Schiller et al., 2002; Khaykin et al., 2013).

Dehydration of Antarctic vortex air masses is observed frequently by satellite measurements (e.g., Nedoluha et al., 2002; Jimenez et al., 2006; Schoeberl and Dessler, 2011). However, satellite measurements in the lower stratosphere and upper troposphere (UT/LS) do not offer the necessary horizontal and vertical resolution to be suitable for process studies in the tropopause region. Balloon-borne measurements launched from the Antarctic continent also observed dehydration and the corresponding rehydration (e.g., Vömel et al., 1995). Beside these balloon soundings, only three aircraft campaigns have been conducted where Antarctic stratospheric air masses were probed in situ: two US campaigns with the ER-2 aircraft (AAOE in 1987; Tuck et al., 1989, and ASHOE in 1994; Tuck et al., 1997a) and one European campaign with the Geophysica aircraft (APE-GAIA in 1999; Giovanelli et al., 2005). Airborne in situ measurements in the Antarctic vortex are very rare, since the flight range of research aircraft is limited. This paper focuses on one measurement flight directly into the Antarctic vortex that was performed as part of the ESMVal (Earth System Model Validation; Schlager, 2014) campaign in September 2012 with the German research aircraft HALO (High Altitude and LOng Range; Krautstrunk and Giez, 2012). The ESMVal campaign was embedded in the TACTS (Transport And Composition in the Upper Troposphere/Lowermost Stratosphere; Engel et al., 2013) campaign, which took place just before and after the ESMVal flights in August and the end of September 2012. A mutual scientific objective of both campaigns was to investigate the transition region between the troposphere and stratosphere. HALO was equipped with in situ instruments as well as the high-resolution limb sounder GLORIA (Gimballed Limb Observer for Radiance Imaging of the Atmosphere). This combination of high-precision in situ measurements together with sophisticated remote sensing observations in the UT/LS is an outstanding attribute of both campaigns. Another objective of the ESMVal flights was to obtain a full meridional cross section of atmospheric measurements for global chemistry model evaluation. The Antarctica flight was performed in an effort to penetrate as far south as possible and reach the stratospheric vortex. During this flight, dehydrated air masses were measured in situ far north up to $45^{\circ} \mathrm{S}$ between 12 and $13 \mathrm{~km}$. In contrast, Aura-MLS and POAM 3 satellite measurements (Nedoluha et al., 2002; Jimenez et al., 2006; Schoeberl and Dessler, 2011) do not show dehydrated air masses as far north (not beyond $57^{\circ} \mathrm{S}$ ) and as low in the stratosphere and upper troposphere as was observed during this ESMVal flight. This is mostly caused by the poor spatial resolution of satellites in the UT/LS region.

In general, the process of dehydration is well understood. Relatively little is known about the fate of the dehydrated air masses at the bottom of the stable vortex. Tuck et al. (1997b) found out that dehydrated air masses descend downwards through the bottom of the vortex down to the thermal tropopause. Normally, the air within the Antarctic polar vortex is highly isolated with a weak exchange of trace gases across the vortex edge driven by stratospheric planetary Rossby waves propagating from the troposphere and Rossby wave breaking (RWB) events. However, the RWB events mainly disturb the bottom of the polar vortex, where the vortex edge barely exists as an isolating mechanism. Mixing and transport of dehydrated air masses from the Antarctic lower stratosphere towards midlatitudes is also indicated by a previous aircraft mission with the ER-2 (Tuck, 1989). Thus, the Antarctic lowermost stratosphere consists of dehydrated air masses frequently mixed with moist midlatitude air (Tuck et al., 1997b; Lee et al., 2002). The vortex edge in the Southern Hemisphere is typically less strongly disturbed than in the Arctic due to less wave activity (Schoeberl et al., 1992). For instance, Khosrawi et al. (2006) presented a case study where dehydration was observed in the Northern Hemisphere midlatitude in connection with a polar filament.

Nevertheless, Antarctic stratospheric air masses can also be exchanged with tropospheric air masses (stratospheretroposphere exchange (STE)) and can be transported deep into the troposphere creating a dry tongue reaching down to the Earth's surface. This air is rich in ozone and reactive nitrogen due to the stratospheric origin and can influence the chemical composition of the Antarctic troposphere (Stohl and Sodemann, 2010; Mihalikova and Kirkwood, 2013). The thermal tropopause, for instance, is characterized by a low temperature lapse rate $\left(\leq 2 \mathrm{~K} \mathrm{~km}^{-1}\right)$ and coincides with a change in the static stability. Thus, the thermal tropopause separates the unstable troposphere from the stable stratosphere. However, the thermal tropopause in the Antarctic region is formed under unique climate conditions (Evtushevsky et al., 2011). The upper troposphere and lower stratosphere are generally very cold with a very weak vertical temperature gradient during winter and spring. Therefore, the thermal tropopause in the Antarctic region is rather poorly defined (Stohl and Sodemann, 2010). As a consequence, transport across the thermal tropopause can be either along isentropes crossing the thermal tropopause or diabatic with reduction in potential temperature. In addition, Zängl and Hoinka (2001) showed that the definition of the thermal tropopause in the Antarctic winter is not very meaningful in contrast to the potential vorticity (PV)-based tropopause definition.

Stohl and Sodemann (2010) identify two general processes that transport stratospheric air masses down to near-surface levels. The first process might involve katabatic winds at the surface over the Antarctic Plateau caused by the high topography that create a general downwelling above the Antarctic continent as suggested by Roscoe (2004). The second process is driven by midlatitude cyclones on the poleward side of the jet stream that support RWB events and a corresponding stratospheric intrusion as reported by Ndarana et al. (2012). 
Downward transport could be either very fast along tilted isentropes on timescales of 1-5 days (Škerlak et al., 2014) or slower by radiative cooling and reduction in potential temperature. In the latter case, air masses can potentially descend from the thermal tropopause to near-surface heights within 10 days (descent rate of $5 \mathrm{~mm} \mathrm{~s}^{-1}$ ) or longer as reported by van de Berg et al. (2007). Rossby wave-induced stratospheric intrusions, such as tropopause folds, occur more often further north and in the midlatitudes than directly above the Antarctic continent (Sprenger et al., 2003; Škerlak et al., 2014). However, the frequency, the seasonality, and the process behind tropopause folds and stratospheric intrusions in the Antarctic region are still under debate (Stohl and Sodemann, 2010; Ndarana et al., 2012; Mihalikova and Kirkwood, 2013).

The following research questions will be answered, based on the observations of the ESMVal flight (13 September 2012): (1) can we confirm dehydration in the lowermost stratosphere and at the bottom of the Antarctic vortex? (2) How deep do dehydrated air masses from the vortex descend into the troposphere? (3) Where and how have Antarctic dehydrated stratospheric air masses been transported?

To answer the questions above, the study presented here is structured as follows: in Sect. 2, a brief overview of the different instruments and data used is given. The in situ and remote sensing measurements across the Antarctic polar vortex are described in Sect. 3. Furthermore, Sect. 4 includes an extensive trajectory case study. First, dehydration in the in the Antarctic lowermost stratosphere is analyzed. Second, the transport of dehydrated air masses and the question how deep below the thermal tropopause dehydrated air masses can be found is investigated.

\section{Instrumentation and meteorological data}

The German research aircraft HALO, deployed during TACTS and ESMVal, has a long flight endurance of up to $12 \mathrm{~h}$. This allows air masses in the Antarctic vortex to be sampled from Cape Town without intermediate landing in Antarctica. Altogether, a set of nine in situ instruments for measuring trace gases and one remote sensing instrument were installed aboard HALO. For the study presented here, we use the water vapor data of FISH and HAI as well as measurements from TRIHOP for methane and FAIRO for ozone. The remote sensing instrument GLORIA provides cross sections of trace gases that are approximately parallel to the flight track of the aircraft. GLORIA's high vertical resolution makes it particularly suited for the investigation of small-scale structures. In addition to the aircraft measurements, satellite observations from CALIPSO and meteorological reanalysis data from ECMWF are used for further interpretation of the observed situation. The instruments and meteorological data are described in the following subsections. The thermal tropopause definition in this study is based on the WMO definition (WMO, 1957) using the lowest height at which the temperature lapse rate decreases to $\leq 2 \mathrm{~K} \mathrm{~km}^{-1}$ and remains below this value for a range of at least $2 \mathrm{~km}$.

\subsection{FISH - total water measurements (in situ $\mathrm{H}_{2} \mathrm{O}$ )}

The airborne Lyman- $\alpha$ photofragment fluorescence hygrometer FISH (Fast In-situ Stratospheric Hygrometer) is a wellestablished closed-path instrument for measuring water vapor in the range of 1 to 1000 ppmv (Zöger et al., 1999). FISH is specially designed for measuring the low water vapor mixing ratios prevailing in the upper troposphere and lower stratosphere. It is regularly calibrated on the ground to a reference frost point hygrometer (MBW DP30) and had an accuracy of $\pm(6 \%+0.4 \mathrm{ppmv})$ during the TACTS and ESMVal campaigns (Meyer et al., 2015). The air supply for the measuring cell is provided by a forward-facing inlet, which also samples ice crystals if present $\left(\mathrm{H}_{2} \mathrm{O}_{\text {cond }}\right)$. Together, the evaporated crystals and the gas-phase water $\left(\mathrm{H}_{2} \mathrm{O}_{\text {gas }}\right)$ sum up to a total water measurement.

\subsection{HAI - total water measurements (in situ $\mathrm{H}_{2} \mathrm{O}$ )}

The Hygrometer for Atmospheric Investigation (HAI) (Buchholz, 2014) is a fast, airborne, in situ hygrometer capable of multi-phase water detection that employs direct tunable-diode laser absorption spectroscopy (dTDLAS) in combination with a special data retrieval method which allows absolute water vapor measurements without any sensor calibration (Buchholz et al., 2013). This data retrieval was recently successfully validated via a direct side-by-side comparison with the German metrological water vapor scale (Buchholz et al., 2014). HAI is a $2 \times 2$, multi-channel TDLAS spectrometer which realizes, in a unique concept, a simultaneous gas-phase and total water measurement via parallel water detection in an open-path cell, outside the aircraft fuselage, and in extractive (i.e., gas sampling) closedpath cells inside the aircraft. To enlarge the dynamic range to $1-40000 \mathrm{ppmv}$, both cell types are simultaneously probed by two laser wavelengths, at $1.4 \mu \mathrm{m}$ for the lower to midtroposphere and at $2.6 \mu \mathrm{m}$ for the upper troposphere and the stratosphere. The ranges of the 1.4 and $2.6 \mu \mathrm{m}$ spectrometer channels overlap and therefore provide a redundant, independent detection between 10 and about 5000 ppmv. The metrologically calculated spectrometer uncertainties are $\pm(4.3 \%+3 \mathrm{ppmv})$ at $1.4 \mu \mathrm{m}$ and $\pm(5.9 \%+0.4 \mathrm{ppmv})$ at $2.6 \mu \mathrm{m}$. In this study, data from the two closed-path spectrometers are used, i.e., total water measurements similar to FISH.

\subsection{TRIHOP - methane measurement (in situ $\mathrm{CH}_{4}$ )}

The TRIHOP instrument is a three-channel quantum cascade laser infrared absorption spectrometer capable of the subsequent measurement of $\mathrm{CO}, \mathrm{CO}_{2}, \mathrm{~N}_{2} \mathrm{O}$ and $\mathrm{CH}_{4}$. During 
TACTS/ESMVal the instrument was calibrated in situ against secondary standards of compressed ambient air which are traceable against NOAA standards. Integration time for each species was $1.5 \mathrm{~s}$ at a duty cycle of $8 \mathrm{~s}$, which finally limits the temporal resolution of the measurements. For the ESMVal flight on 13 September 2012, TRIHOP $\mathrm{CH}_{4}$ data achieved a precision $(2 \sigma)$ of $9.5 \mathrm{ppbv}$ and accuracy of $13.5 \mathrm{ppbv}$ without any corrections applied.

\subsection{FAIRO - ozone measurement (in situ $\mathrm{O}_{3}$ )}

FAIRO is a new accurate ozone instrument developed for use onboard the HALO aircraft. It combines two techniques, the UV photometry (light absorption of $\mathrm{O}_{3}$ at $\lambda=250-260 \mathrm{~nm}$ ) with high accuracy and chemiluminescence detection with high measurement frequency. A UV-LED is used as a light source for the UV photometer, which can be controlled well (in contrast to $\mathrm{Hg}$ lamps) for constant light emission. The $1 \sigma$ precision is $0.08 \mathrm{ppbv}$ at a measurement frequency of $4 \mathrm{~s}$ and a cuvette pressure of $1 \mathrm{bar}$ and the total uncertainty is $2 \%$. The chemiluminescence detector shows a measurement frequency of $12.5 \mathrm{~Hz}$ and a high precision of $0.05 \mathrm{ppbv}$ (at $10 \mathrm{ppbv}$ absolute, a measurement frequency of $5 \mathrm{~Hz}$, and a pressure of 1 bar) (Zahn et al., 2012).

\subsection{GLORIA (aircraft remote sensing)}

The Gimballed Limb Observer for Radiance Imaging of the Atmosphere (GLORIA) combines a two-dimensional focal plane detector array with a Fourier transform spectrometer to capture about 6000 infrared limb spectra simultaneously. This enables remote sensing observations with high vertical and horizontal resolution to resolve small-scale structures (see Riese et al., 2014). The spectral sampling can be switched between 0.625 and $0.0625 \mathrm{~cm}^{-1}$ at the cost of an increased acquisition time in the case of higher spectral resolution (Friedl-Vallon et al., 2014). The gimbal mount and inertial altitude control system allows GLORIA to maintain a steady pointing on a moving aircraft; it can also be used to point the instrument at a range of azimuth angles with respect to the aircraft, covering about $70^{\circ}$. This allows for tomographic measurement patterns and 3-D reconstruction of fine-scale filamentary structures (Ungermann et al., 2011; Kaufmann et al., 2015). The vertical location of retrieved quantities approximately follows the tangent points of the measurement geometry (parabola curve through the atmosphere). Thus, while the location of quantities retrieved at flight level lies in the vicinity of the aircraft, the locations of quantities at lower altitudes are horizontally several tens to hundreds of kilometers away from the flight path. Assuming a flight altitude of $13 \mathrm{~km}$, the water vapor observation at $12 \mathrm{~km}$ is horizontally $113 \mathrm{~km}$ away from the aircraft, while at $8 \mathrm{~km}$ it is already $250 \mathrm{~km}$. Concerning the water vapor product used in this paper, GLORIA achieved a vertical and horizontal resolution of about $500 \mathrm{~m}$ and $100 \mathrm{~km}$, respectively. The water vapor precision and total error (accuracy + precision) amounts to about 0.2 and $1.0 \mathrm{ppmv}$ in the stratosphere. Ungermann et al. (2015) showed that GLORIA water vapor at flight level agrees fairly well with the in situ FISH measurements, within error bars. The deviations to FISH during the ESMVal/TACTS flights are mostly less than 0.4 ppmv.

\subsection{CALIPSO (satellite remote sensing)}

The Cloud-Aerosol Lidar and Infrared Pathfinder Satellite Observation (CALIPSO) satellite is one of five satellites in the NASA A-train constellation. CALIPSO completes 14.55 orbits per day with an inclination of $98.2^{\circ}$ and thus delivers good coverage above the polar regions. In addition to one wide-field camera and an imaging infrared radiometer, the Cloud-Aerosol Lidar with Orthogonal Polarization (CALIOP) is aboard CALIPSO. The lidar operates with two wavelengths (532 and $1064 \mathrm{~nm}$ ) with additional polarization sensitivity, providing high-resolution vertical backscatter profiles of aerosols and clouds. In this study we use the CALIPSO Lidar Level 2 Polar Stratospheric Cloud (PSC) data product, which is described in Pitts et al. (2009, 2011). This data product provides a PSC composition scheme on a daily basis for all nighttime orbits with a resolution of $5 \mathrm{~km}$ horizontally by $180 \mathrm{~m}$ vertically.

\subsection{ECMWF (meteorological data)}

Global meteorological reanalysis ERA-Interim data (Dee et al., 2011) of the ECMWF (European Centre for MediumRange Weather Forecasts) are used to interpret the observations. The meteorological fields have a resolution of $1^{\circ} \times 1^{\circ}$ with 60 vertical levels from the surface $(1000 \mathrm{hPa})$ up to $0.1 \mathrm{hPa}$. Every $6 \mathrm{~h}$ a full global data set is available. The trajectories used in Sect. 4 are based on the horizontal wind fields and diabatic heating rates; additional parameters such as temperature and pressure are added to the trajectories from the ERA-Interim data (for details see Sect. 4).

\section{ESMVal flight on 13 September 2012}

\subsection{Meteorological situation/flight pattern}

The general dynamical situation of the Antarctic vortex is shown in Fig. 1a. High PV values of $<-9$ PVU denote the Antarctic vortex at the $350 \mathrm{~K}$ isentrope, which corresponds approximately to the flight level. The vortex edge is marked with a blue line according to the definition of Nash et al. (1996). The vortex itself is shifted about $10^{\circ}$ towards Africa, indicating a wave-one pattern caused by Rossby wave activity. This results in high PV values up to $47^{\circ} \mathrm{S}$, where the aircraft in situ measurements confirm the presence of Antarctic vortex air as will be shown later (see Sect. 3.2). In the lowermost stratosphere below the vortex, represented by the $310 \mathrm{~K}$ 


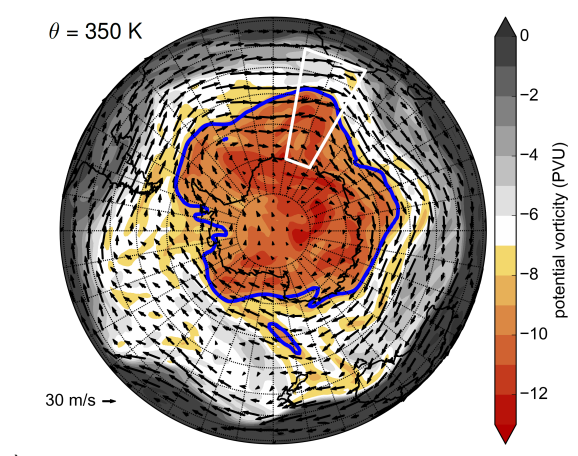

a)

Figure 1. Dynamical situation with color-coded PV from ECMWF data on 13 September 2012 at 12:00 UTC on two different potential temperature levels: (a) $350 \mathrm{~K}$ and (b) $310 \mathrm{~K}$. The black arrows depict the wind vectors. The blue line represents the vortex edge at $350 \mathrm{~K}$ (Nash et al., 1996) and the green line the -2 PVU isoline at the $310 \mathrm{~K}$ level. The region of the ESMVal flight is marked by a white box.

isentrope (see Fig. 1b), the PV structure with high PV values around -6 to -3 PVU is more jagged but mostly connected. Here, a strong Rossby wave activity is visible and also RWB events associated with isolated PV structures are discernible. A blob with high PV at 60 to $47^{\circ} \mathrm{S}$ and 10 to $30^{\circ} \mathrm{E}$ indicates an ongoing RWB event. These air masses were probed during the ESMVal flight on 13 September 2012. The flight was performed from Cape Town (South Africa) heading towards Antarctica until $65^{\circ} \mathrm{S}$ at an altitude of $12-13 \mathrm{~km}$ (see Fig. 2). After a dive from $12.5 \mathrm{~km}$ down to $3 \mathrm{~km}$ to sample the transition from the polar stratosphere to the troposphere, the return flight took place at $12.5 \mathrm{~km}$ and rose up to $15 \mathrm{~km}$ shortly before descending back to Cape Town. A hexagonal flight pattern was included in the flight path back to Cape Town to enable the tomographic study of trace gases with GLORIA. The ECMWF wind field (black lines), as well as the strongly increasing potential vorticity (PV; see Fig. 3), shows that the vortex edge (yellow dots, determined with the Nash criterion) was far north, up to $47^{\circ} \mathrm{S}$ down to the $340 \mathrm{~K}$ level. The color code in Fig. 2a represents the in situ-measured water vapor mixing ratios from FISH along the flight path. Directly south of the vortex edge the water vapor mixing ratios decrease rapidly to below $2.5 \mathrm{ppmv}$ (purple dots along the flight path).

The latitudinal cross section of PV from ECMWF along the flight path is shown in Fig. 2b. The thermal tropopause (cyan dots) stays almost constant at around $10 \mathrm{~km}$ and rises up to $12 \mathrm{~km}$ further poleward. The PV and also the equivalent latitude (not shown) reveal high values within the vortex and thus clearly mark the vortex air masses. However, high PV values of -2 PVU show up far below the thermal tropopause down to $5 \mathrm{~km}$ altitude in the latitude range from 60 to $45^{\circ} \mathrm{S}$. The difference compared to a tropopause fold at the midlatitude jet is that the air masses directly originate from the Antarctic vortex and were strongly dehydrated. Thus, the air masses have a different chemical composition than the "normal" air masses in the midlatitude lowermost stratosphere. This indicates that these air masses originate from higher altitudes and were transported through the ther- mal tropopause and form a stratospheric intrusion with a low PV-based tropopause. Interestingly, the isentropes between 310 and $320 \mathrm{~K}$ intersect the thermal tropopause on the poleward side of the jet core. Therefore, air masses can be potentially transported along these tilted isentropes to the low altitudes across the thermal tropopause into the low PV structure. The flight path crosses the air masses with high PV in the stratosphere before and after the dive. The dive down to $3.5 \mathrm{~km}$ altitude was performed on the poleward side of the air masses with high PV below the thermal tropopause.

\subsection{Observations}

The time series of the in situ measurements are shown in Fig. 3, where the measurements of the water vapor instruments are visible in the upper panel and the measurements of the tracers for defining stratospheric/vortex air masses are shown in the lower panel. After the ascent of HALO near Cape Town, the water vapor mixing ratio decreases to the typical stratospheric value of 4 ppmv, from 06:30 until 08:15 UTC. During this time, ozone and PV (i.e., the stratospheric tracers with low values in the troposphere) show an increase compared to the values before 06:30 UTC, while methane (tropospheric tracer with low values in the stratosphere) shows a slight decrease from 1790 to $1740 \mathrm{ppbv}$. Both indicate that the aircraft entered the stratosphere. Thereafter, methane and water vapor further decrease to $1650 \mathrm{ppbv}$ and 3 ppmv, respectively, on the same flight level starting at 08:15 UTC, and simultaneously ozone and PV further increase. This is the time when HALO penetrated the Antarctic vortex (marked in blue in Fig. 3). After ascending to a higher flight level (08:35 UTC), water vapor decreases to slightly above 2 ppmv and stays there until the southernmost point was reached and the dive started at 11:00 UTC. This low water vapor in the time between 08:15 and 11:00 UTC coincides well with high PV values (see Fig. 2b). Subsequently, the strong increase in methane and decrease in ozone and PV indicate the penetration of the aircraft into the Antarctic tro- 


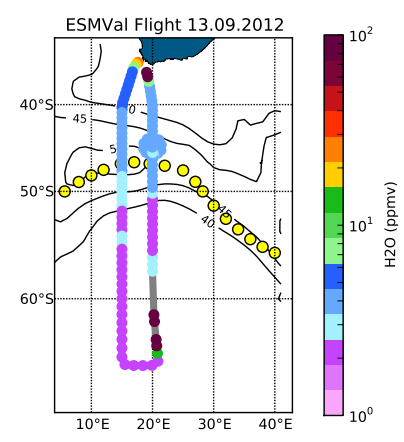

a)

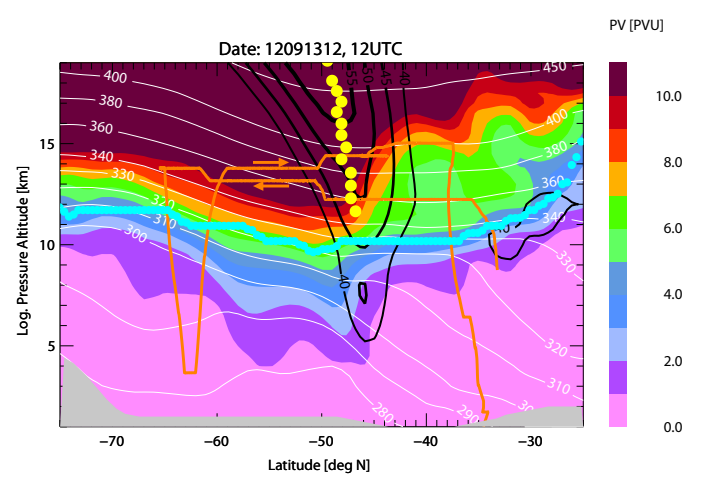

b)

Figure 2. Flight pattern of the ESMVal flight on 13 September 2012. The black contours illustrate the horizontal westerly wind from ECMWF data. Yellow dots represent the vortex edge derived from the Nash criterion (Nash et al., 1996) based on ECMWF data. (a) Horizontal map of water vapor mixing ratios measured by FISH ( 5 min averaged data) is color-coded on the flight path (gray indicates data gaps due to the dive). (b) Meridional cross section of PV along the flight path (orange line) calculated from ECMWF data. Cyan dots represent the ECMWF thermal tropopause.

posphere at 11:00 UTC. After returning to the previous flight level (11:45 UTC), the vortex signatures with low values of water vapor and methane as well as high values of ozone and PV show up again. However, at this point $(\sim 12: 30$ UTC) the water vapor mixing ratio reaches the lowest value of $1.6 \pm 0.5 \mathrm{ppmv}$ together with a strong maximum in ozone and PV. The low water vapor below 4 and even below 2 ppmv indicates strongly dehydrated air masses.

The saturation mixing ratio with respect to ice within the vortex is 3 to 4 times larger than the measured water vapor mixing ratio. Thus, the sampled air masses were clearly subsaturated with relative humidities of $25-33 \%$ and it is unlikely that ice particles remained in the probed air masses. In addition, HAI and FISH show no peaks in the total water vapor time series (based on $1 \mathrm{~Hz}$ data), which would indicate the presence of ice particles on the flight level. In particular, the water vapor mixing ratios around 2 ppmv during the stratospheric flight legs (06:30 to $11: 00$ and 11:45 to 15:45 UTC) are very smooth and show no significant variations. Thus, both water vapor instruments, FISH and HAI, measured only gas-phase water vapor, and no cloud particles were present in the vortex air. Both FISH and HAI observed these low water vapor mixing ratios independently.

In order to show the fairly good agreement of both FISH and $\mathrm{HAI}$ based on $1 \mathrm{~Hz}$ data at the observed low water vapor values, we choose two flight legs for the comparison (leg one: 09:45-10:45 UTC; leg two: 13:00-14:00 UTC). During flight leg one, both hygrometers have an absolute difference of $0.21 \mathrm{ppmv}$ and a mean relative difference of $-14.9 \%( \pm 10.5 \%, 1 \sigma)$. During flight leg two, a difference of $0.26 \mathrm{ppmv}$ and a mean relative difference of $-5.9 \%$ $( \pm 7.3 \%, 1 \sigma)$ is found. These rather small differences are consistent with the uncertainties of both hygrometers, which are \pm 0.45 and \pm 0.5 ppmv at the 2 ppmv level for FISH and HAI, respectively. The HAI data measured before 09:10 UTC (marked with gray in Fig. 3) are influenced by an untypical memory effect of the measurement cell during ascent, caused by a valve which was opened too late, but only when flying in the upper troposphere. As a result, the "wet" measurement cells were not sufficiently dried off with the high mass flows during take-off and ascent. This also explains the asymmetry in the deviations to FISH before and after the dive. In addition, the agreement of GLORIA water vapor observations at flight level with the two in situ instruments, FISH and HAI, is remarkably good, considering that GLORIA is a remote sensing instrument.

The GLORIA instrument measures quasi-vertical profiles along the flight path by viewing the atmosphere on the right side of HALO. Here, we focus on the $\mathrm{H}_{2} \mathrm{O}$ retrieval product, which is shown in Fig. 4. We consider only the times from 08:00 to 14:00 UTC to focus on a time period when GLORIA observed vortex air (the whole data set is from 06:30 to 15:30 UTC). The dive is noticeable as the white area between 11:00 and 12:00 UTC, where GLORIA did not measure in order to prevent condensation of tropospheric water vapor on the cold instrument. The dry vortex air masses are clearly visible between 08:00 and 13:00 UTC at flight level (black solid line in Fig. 4) but also below, down to altitudes of $7 \mathrm{~km}$. As mentioned in Sect. 2.5, the quantities retrieved from GLORIA are approximately placed on a parabola following the tangent points through the atmosphere (e.g., $250 \mathrm{~km}$ horizontal distance to flight path at $9 \mathrm{~km}$ altitude). The dry region just before the dive was measured by GLORIA west of the flight path on the way towards Antarctica, while the air masses after the dive are measured east of the flight path on the way back to Cape Town. Thus, the dehydrated air masses below the thermal tropopause cover a large region, with a dimension of at least $500 \mathrm{~km}$ horizontally at $9 \mathrm{~km}$ altitude.

The thermal tropopause is also derived from the GLORIAretrieved temperature profiles and is marked with black dots. 


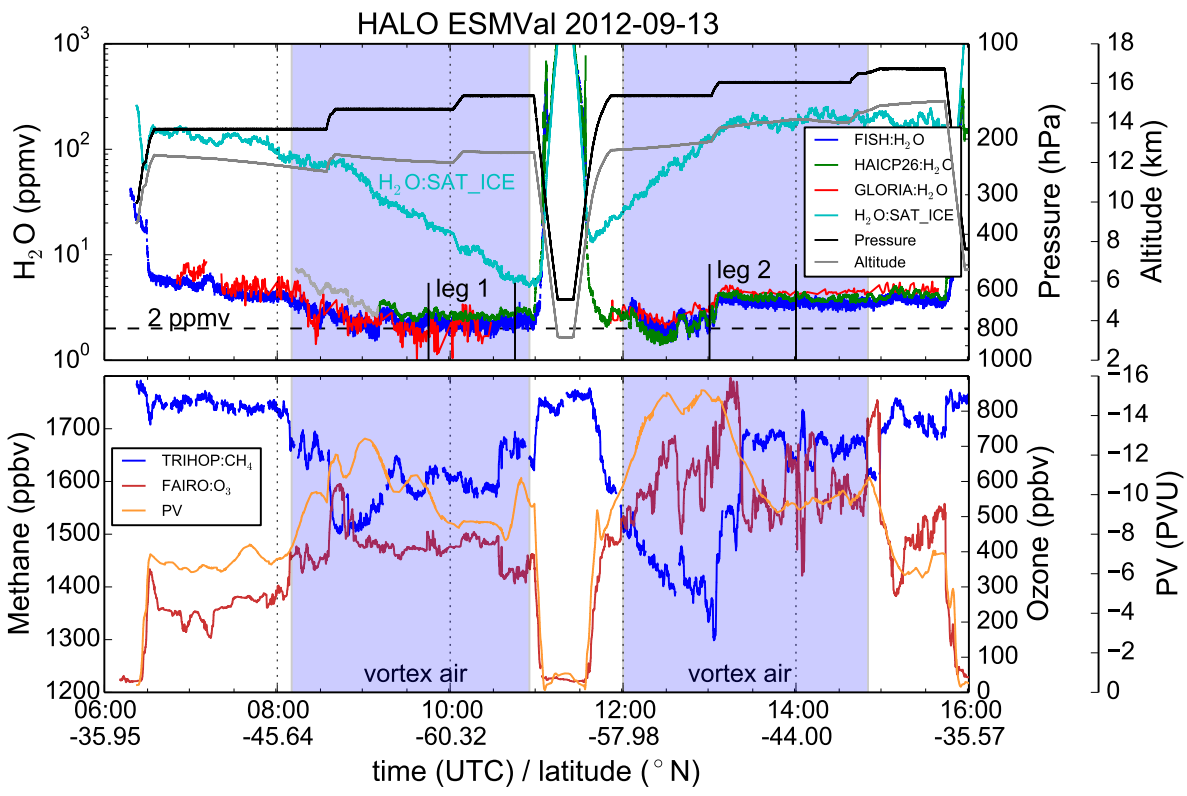

Figure 3. Time series of ESMVal Antarctica flight on 13 September 2012: the upper panel shows FISH (blue), HAI (green) and GLORIA (red) water vapor measurements, water vapor saturation mixing ratio with respect to ice (cyan, derived from HALO temperature), pressure (black), and altitude (gray) at flight level. The lower panel shows the tracer observation ozone (red), methane (blue) and interpolated ECMWF $\mathrm{PV}$ values (orange). Time ranges within the vortex are marked with light-blue shadows according to the tracer measurements. Time ranges leg one and leg two are marked for hygrometer intercomparison of FISH and HAI (see text).

Interestingly, low water vapor mixing ratios around and below 2 ppmv are observed beneath the thermal tropopause. Especially in the time range from 09:00 to 10:30 UTC and from 12:00 to 13:30 UTC, very dry air masses with water vapor mixing ratios of $2-3$ ppmv can be found far below the thermal tropopause, down to $7 \mathrm{~km}$. This indicates that dehydrated stratospheric air masses could have been transported through the thermal tropopause. The dynamic tropopause, which is between the -4 and -2 PVU isoline, is somewhat lower than the thermal tropopause at $\sim 7 \mathrm{~km}$ in the time range from 12:00 to 13:30 UTC and indicates a proceeding stratospheric intrusion. In Sect. 4.2, we analyze this transport process with the help of air mass backward trajectories. In addition, no water vapor values less than $6 \mathrm{ppmv}$ are found below the -4 PVU isoline in ECMWF data (not shown here). This shows, at least for this situation, that the transport process of dry stratospheric air masses to these low altitudes we observed here is not captured by the ECMWF meteorological analysis (see Sect. 4).

Embedded in the dry vortex air masses, small filaments (marked in Fig. 4 with red boxes) of enhanced water vapor are visible. These filaments may indicate rehydration layers, where sedimented ice particles from upper layers have sublimated and resulted in layers of enhanced water vapor as described in, for example, Khaykin et al. (2013) for the Arctic. However, trajectory reverse domain filling (RDF) (Sect. 4.2) showed that these air masses could not be attributed to rehydration. Also, the in situ measurements of FISH/HAI showed no evidence of a rehydration layer during the dive from $\sim 12.5$ to $3 \mathrm{~km}$ and back. We have analyzed these somewhat moister air masses in more detail, as discussed in the next section.

\section{Trajectory-based case study of 13 September 2012}

Detailed investigation of the observed Antarctic dehydration is performed using air mass trajectories calculated with the tool CLaMS-traj, which is part of the Chemical Lagrangian Model for the Stratosphere (CLaMS) (McKenna et al., 2002; Konopka et al., 2007). The trajectories are driven by the ERA-Interim reanalysis horizontal winds and diabatic heating rates (Dee et al., 2011; Ploeger et al., 2010). To resolve transport processes in the troposphere influenced by the orography and transport processes in the stratosphere where adiabatic horizontal transport dominates, the hybrid $\sigma-\theta$ coordinate $\zeta$ is used (Mahowald et al., 2002). Therefore, in the stratosphere and in the UT/LS, potential temperature $\theta$ is employed as the vertical coordinate of the model and the cross-isentropic velocity $\dot{\theta}=Q$ is deduced from the ERAInterim forecast total diabatic heating rates $Q$, including the effects of all-sky radiative heating, latent heat release and diffusive heating as described by Ploeger et al. (2010). In the tropospheric region defined by the condition $\sigma=0.3$, the vertical model coordinate smoothly transforms into an orography-following $\sigma=p / p_{\mathrm{s}}$ coordinate $\left(p-\right.$ pressure; $p_{\mathrm{s}}$ - surface pressure), with the vertical velocity transforming 


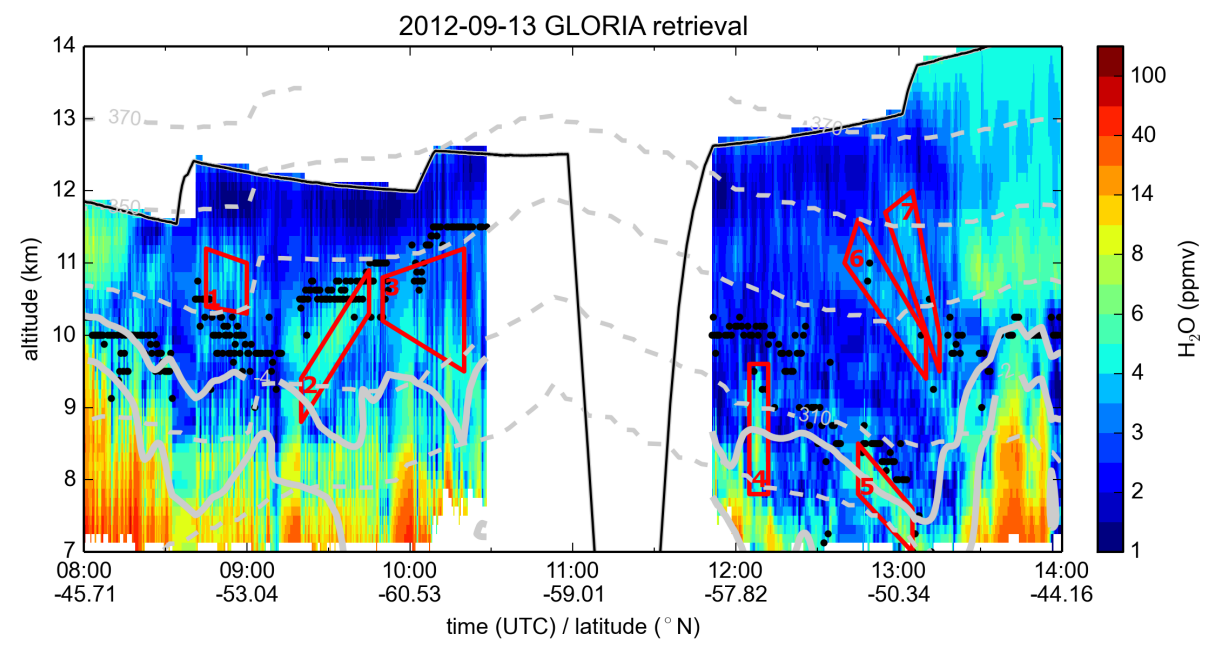

Figure 4. GLORIA time series of the $\mathrm{H}_{2} \mathrm{O}$ retrieval product (13 September 2012). The solid black line and the black dots represent the flight path and thermal tropopause derived from the GLORIA temperature measurements, respectively. The dashed gray lines and the solid lines mark isolines of potential temperature $(290-370 \mathrm{~K}, \Delta \theta=20 \mathrm{~K})$ and PV ( -2 and $-4 \mathrm{PVU})$, respectively. The red boxes marks filaments (1-7) with slightly enhanced water vapor mixing ratios in or below the vortex.

into the corresponding $\dot{\sigma}$ (Pommrich et al., 2014). Besides temperature, pressure, and humidity along the trajectories, the potential vorticity (PV) and thermal tropopause height (WMO, $<2 \mathrm{~K} \mathrm{~km}^{-1}$ lapse rate criterion) are derived from the ECMWF meteorological fields. The temperatures from ECMWF along the flight path agree very well with the measured temperatures from the HALO aircraft (not shown here). The mean deviation on each flight level is mostly around $0.4 \mathrm{~K}$, and the temperatures in ECMWF are slightly lower than the measured temperatures.

In the following we will use the trajectory analysis to investigate the timescale and location of potential dehydration events. In a second step we will analyze the trajectory data for possible exchange into the Antarctic troposphere.

\subsection{History of dehydrated air masses along flight path}

In this section, we investigate the history of the in situmeasured dehydrated air masses. For that purpose, the trajectories are calculated every $10 \mathrm{~s}$ along the flight path, each reaching 50 days backwards in time. For further analysis, we selected all trajectories between 12:20 and 12:29 UTC (in total 54), when the lowest water vapor mixing ratios were measured. However, the other trajectories with measured low water vapor mixing ratios between 2 and 3 ppmv show a very similar history. Figure 5 shows the median saturation mixing ratio with respect to ice (orange line) and the frequency distribution (grayscale color code) of every $1 \mathrm{~h}$ trajectory time step of all trajectories calculated by ClaMS along the 50 days back in time. The trajectories show the same history in saturation mixing ratio from 13 September until 14 August, when the trajectories start to diverge. This indicates that the trajectories have the same path with the same temperature history for at least 30 days. After this time, the trajectories split up into two branches, indicating a bifurcation point and associated mixing on 14 August. The trajectories within the branch with lower saturation mixing ratios of 2 to 3 ppmv below the median line stay together on the same path until the beginning of August. The trajectories before 1 August have different saturation mixing ratios indicating the dispersion of air masses, which limits the interpretation of the trajectory calculations.

To show the presence of ice particles and subsequent dehydration, CALIPSO data (see Sect. 2.6) are used. A distance criterion is used to match the air mass trajectories with the CALIPSO data. Every trajectory at a specific time which coincides with the CALIPSO orbit inside a square of $\pm 5^{\circ}$ latitude and $\pm 5^{\circ}$ longitude is checked for the presence of ice in an altitude range of $\pm 0.2 \mathrm{~km}$. If more than $50 \%$ of all trajectories at one time coincide with a CALIPSO ice observation, the corresponding time periods are marked with a blue bar (see Fig. 5).

Figure 5 illustrates the coincidence of low saturation mixing ratios along the trajectories with observed ice formation (CALIPSO) in the considered air masses. The trajectories pass several cold regions associated with low saturation mixing ratio where ice formation is initiated. If the ice cloud and supersaturation exist long enough (typically around 0.5-1 days; Nedoluha et al., 2002) to allow the ice particles to grow to sizes of several micrometers (diameter of 10 to $20 \mu \mathrm{m}$ ), sedimentation of these ice particles begins and causes irreversible dehydration. The sedimented ice particles with these sizes fall with velocities of around $2.5 \mathrm{~km} \mathrm{~d}^{-1}$ (see Müller and Peter, 1992) until warmer temperatures in lower regions causes them to evaporate. With each pass of a cold region, more and more water vapor is removed from the air 


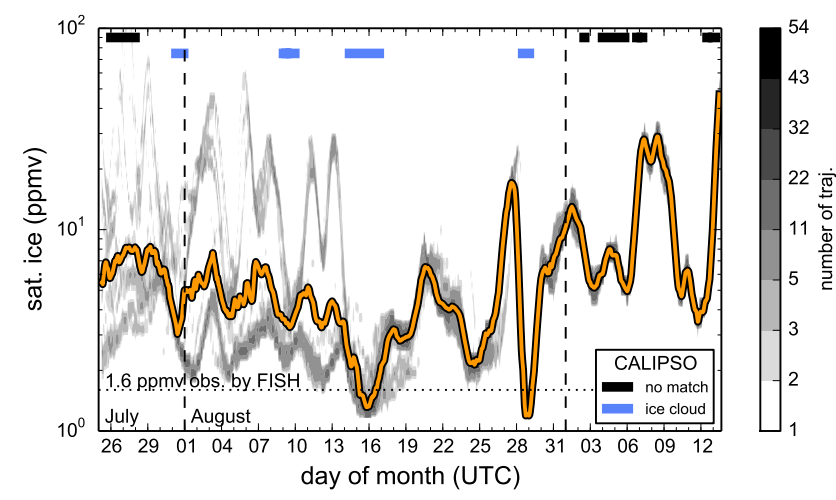

Figure 5. Calculated frequency distribution (number, gray shadow) and median (orange line) of ice saturation mixing ratio along trajectories 50 days back in time starting at the flight path on 13 September 2012 (12:20 to 12:29 UTC, 54 trajectories in total). If more than $50 \%$ of trajectories have a corresponding CALIPSO observations of ice or no ice, the time is marked with blue or white, respectively. Otherwise, it is marked in black, indicating no CALIPSO match.

mass. As stated by Nedoluha et al. (2002), air masses must undergo several periods with dehydration before reaching the 1 to 2 ppmv mixing ratio level, which is typically observed by satellites within the vortex in the Antarctic spring. This periodic behavior is confirmed by Fig. 5, where trajectories undergo four events with low saturation mixing ratios and simultaneous ice cloud observations by CALIPSO. The first and the second period ( 1 and 9 August) reveal rather high saturation mixing ratios of around 3 ppmv. In every later period, colder temperatures and lower saturation mixing ratios are necessary to initiate additional ice formation and dehydration. This is the case during the third and the fourth period on 16 and 29 August, when CALIPSO observed ice show lower saturation mixing ratios of 1.5 and $1.2 \mathrm{ppmv}$, respectively. The last two events will have dried out the air masses to the final state of about $1.6 \mathrm{ppmv}$, which is observed by the FISH and HAI instruments. After this strong dehydration, the temperatures became warmer in the late Antarctic spring and summer and no additional dehydration took place according to the simulations.

The recurring low saturation mixing ratios and corresponding low temperatures are primarily caused by gravity waves, which are induced by the high topography of the Antarctic continent (Stohl and Sodemann, 2010). In particular, the first three ice formation events occurred just as the trajectories passed the Antarctic Peninsula (northernmost part), which is a strong source of gravity waves (e.g., Ern et al., 2011; Hoffmann et al., 2013). Only the last freezing event with the lowest supersaturation occurs above the Antarctic Plateau (central part) in the northeast of the continent.

After freezing, the ice particles can even reach the troposphere due to sedimentation, especially if dehydration takes place at low altitudes $(11.5-12.5 \mathrm{~km})$ as revealed by the trajectories. The lack of rehydration signatures in the GLORIA measurements (see Fig. 4) also indicates the permanent removal of water vapor from the stratosphere, as will be further discussed in Sect. 4.2. The air masses from which the ice particles originate and the air masses where they potentially sublimate in the troposphere behave very differently in dynamical perspective (not shown). Due to the length of time since the last dehydration on 28 August (16 days before measurement) it is very unlikely that rehydrated air masses would still be found below the observed dehydrated air masses in the troposphere. In addition, the in situ measurements taken during the dive confirm the absence of any observed rehydration features.

\subsection{History of air masses observed by GLORIA}

The trajectories for analyzing the transport of dehydrated air masses observed by GLORIA are calculated 70 days backward in time from each tangent point (in total 30000 single trajectories). In addition, the trajectories are also calculated 14 days forward to show where the air masses are further transported. With this set of trajectories, the GLORIA measurements can be interpreted and the associated transport pathways can be investigated.

In the first subsection hereafter, the dehydrated air masses observed with the in situ instruments and GLORIA in the lowermost stratosphere are analyzed and the origin of moist filaments is investigated. The second subsection contains the trajectory analysis of dry air masses found to be below the thermal tropopause and investigates the further transport.

\subsubsection{Vortex air masses}

From the in situ ozone and methane measurements, it is visible that the HALO aircraft has penetrated the Antarctic vortex (see Sect. 3.2). The identification of vortex air masses in the GLORIA trace gas cross sections is performed using the tangent point trajectories. Figure 6 shows the amount of time that the trajectory for each GLORIA tangent point stayed within the vortex before the measurement took place. To calculate this so-called vortex indicator, the vortex border needs to be determined at each trajectory time step with the Nash criterion (Nash et al., 1996). Then, the time that each individual trajectory remains within the vortex border is counted backwards from the time of measurement. This procedure is limited to the preceding 50 days. The blue coloring in Fig. 6 shows the trajectories that stay in the vortex for at least the last 50 days. In contrast, air masses that were never in the vortex are indicated by a deep red color. This includes not only tropospheric air but also stratospheric air masses north of $48^{\circ} \mathrm{S}$. Interestingly, strong gradients between former vortex air (blue) and extra-vortex air (red) are evident between 09:00 and 11:00 UTC and also between 11:45 and 12:20 UTC, which exactly follows the measured thermal tropopause (black dots). Here, the lower vortex 


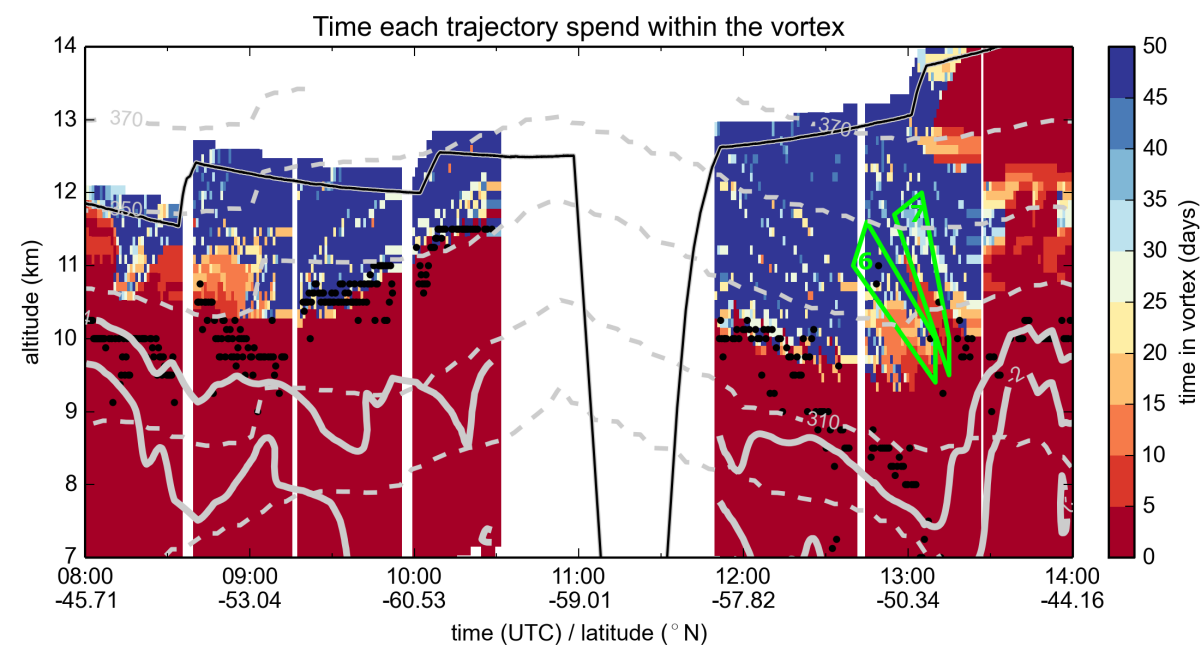

Figure 6. The time each GLORIA tangent point trajectory has spent in the vortex before the measurement. The green boxes mark two of the filaments $(6,7)$ observed by GLORIA (see Fig. 4). The flight path, tropopause height, potential temperature, and PV isolines are the same as in Fig. 4.

boundary defined by (Nash et al., 1996) along the trajectories coincide well with the WMO thermal tropopause.

In contrast, the air masses that spent between 5 and 40 days in the vortex (marked by light-blue and reddish colors) indicate mixing of midlatitude air into the vortex. Even at the vortex edge and in the core of the vortex itself, small filaments are apparent. As indicated in Sect. 3.2, some filaments with elevated amounts of water vapor were also observed with GLORIA. Two of these filaments observed around 13:00 UTC between 10 and $12 \mathrm{~km}$ altitude can be found with this Nash PV criterion showing vortex residence times of 5 days (filament 6 ) and 35 days (filament 7). This shows that these filaments are likely freshly mixed in from outside the vortex and thus could potentially contain higher water vapor content compared to the dehydrated vortex air and therefore weaken the hypothesis of rehydration signatures.

To show that all observed filaments (red boxes in Fig. 4) are caused by mixing, RDF is applied to all trajectories, as already stated in Sect. 3.2 (similar as in Beuermann et al., 2002). For the RDF calculation, only advection and no mixing along the trajectories is assumed. In each time step of the RDF method, the ECMWF water vapor field is interpolated onto the locations of the trajectories and then projected onto the observed time-altitude grid of the GLORIA observations.

Figure 7 shows ECMWF water vapor mixing ratios 5 days prior to the measurement time as projected by the trajectories. The red boxes highlight the position of the water vapor filaments observed by GLORIA (see Fig. 4). With some small deviations in time and altitude, almost all of the observed filaments in the vortex can be reproduced by the RDF method. Note that the RDF method cannot produce the effect of rehydration. This indicates that the water vapor filaments observed by GLORIA were not generated by rehydration but are likely the signatures of moister midlatitude air masses that were mixed into the vortex during the preceding 5 days. Continuing the RDF method further back in time, the filament $7(\approx 12 \mathrm{~km})$ at 13:00 UTC emerges 35 days before observation and indicates the origin to be another mixing event. The time of in-mixing of the filament 7 was already visible in our analysis in Fig. 6. Thus, it seems that these filaments originate from several mixing events, not from a single mixing event only. Furthermore, very dry air masses observed in the time between 09:00 and 10:30 UTC and 12:00 and 13:30 UTC down to $7 \mathrm{~km}$ (see Sect. 3.2) can also be partly reproduced with the RDF method, indicating that transport is the main reason for the occurrence of dry air below the thermal tropopause. The origin of these air masses and the transport mechanism are analyzed and discussed in the next subsection.

\subsubsection{Transport of dehydrated air masses across the thermal tropopause}

The weak vertical temperature gradient and the poor definition of the thermal tropopause is implied by the tropopause heights derived from GLORIA, which have a broad scatter $( \pm 0.5 \mathrm{~km})$ at some places. In addition, the PV gradient along isentropes (i.e., isentropes following the PV isolines) as well as the vertical gradient at the transition between troposphere and stratosphere within the vortex $(08: 30$ 13:30 UTC) is small. The PV isolines $(-4$ and -2$)$ in the vortex have a larger spacing than at the edge (jet region), where the vertical distance between the isolines decreases (08:15 and 13:30 UTC in Fig. 6). As a consequence, the weak isentropic PV gradient along the sloping isentropes facilitate transport to lower altitudes below the location of the thermal tropopause. Subsequent diabatic processes may lead to STE 


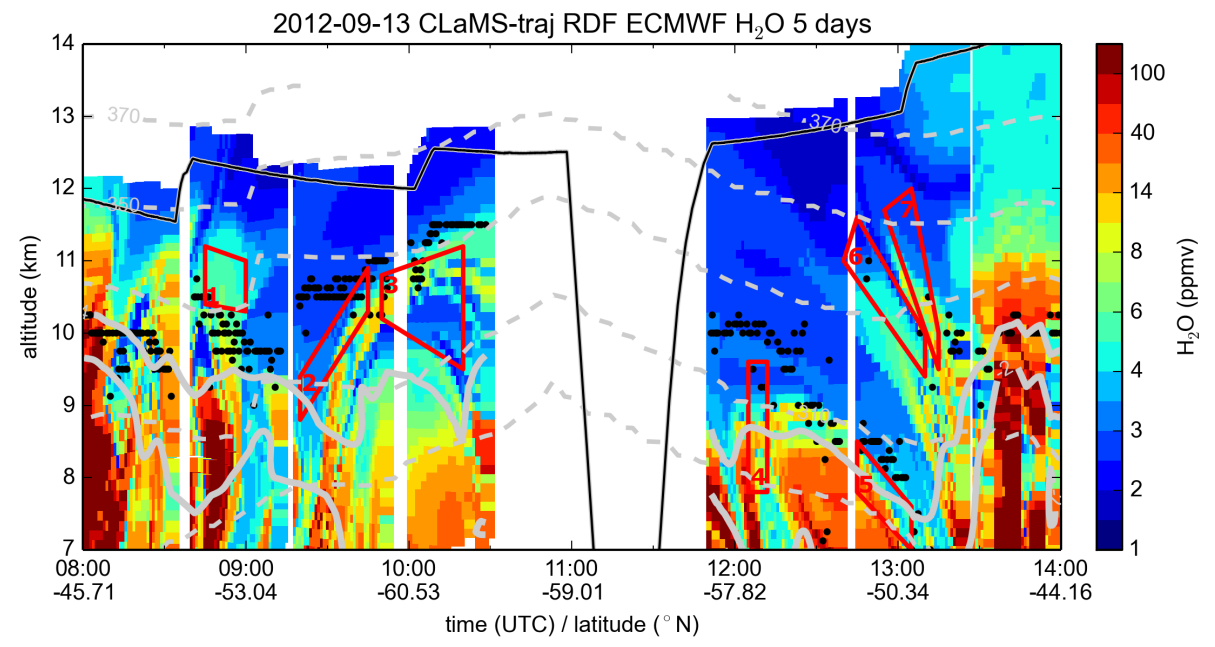

Figure 7. RDF (reverse domain filling) of each GLORIA tangent point trajectory with ECMWF water vapor of 5 days prior to the measurement time. Red boxes show the location of the observed filaments. The flight path, tropopause height, potential temperature, and PV isolines are the same as in Fig. 4.

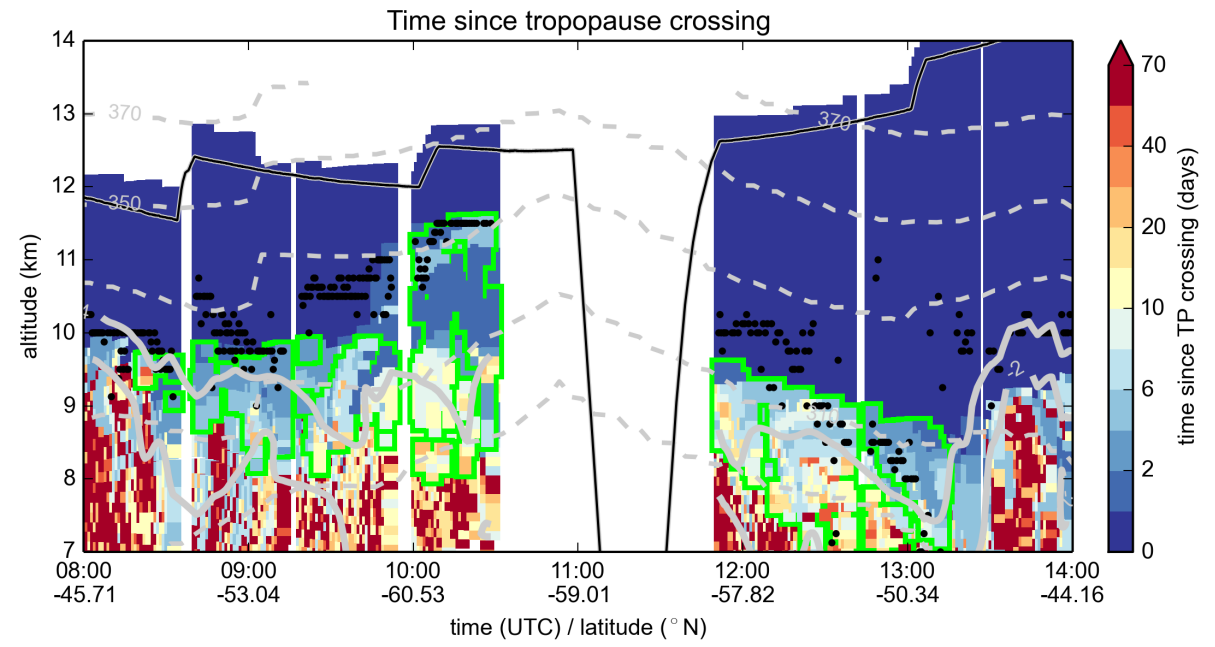

Figure 8. The color code denotes the time since trajectories passed the thermal tropopause from stratosphere to troposphere. Bluish colors denote trajectories which recently passed the thermal tropopause, reddish colors indicate tropopause crossings longer ago. The green-framed areas mark the trajectories where GLORIA observations show water vapor below 3 ppmv. The flight path, tropopause height, potential temperature, and PV isolines are the same as in Fig. 4.

and irreversible exchange with tropospheric air. Especially in the case of planetary wave breaking events that produce stratospheric intrusions, large amounts of air can be transported into the troposphere across the tropopause. Figure 8 shows the time difference between the trajectory initialization time and the first thermal tropopause crossing. This time is determined by counting the trajectory time steps backward in time to wherever the difference in altitude between current tropopause and trajectory is positive. Air parcels having stayed for the last 70 days below the thermal tropopause (dark-red colors) can clearly be assumed to be tropospheric nature. In addition, low PV wave-one pattern values (indica- tor of tropospheric air masses) can be attributed to these air masses as discernible from Fig. $2 b$.

The stratospheric and vortex air masses did not cross the thermal tropopause (dark blue colors). The air masses below the measured thermal tropopause are obviously more patchy and contain more trajectories originating from the troposphere (reddish colors). However, some freshly transported stratospheric air masses are also discernible below the thermal tropopause (light-blue colors), down to $7 \mathrm{~km}$. The green-framed areas in Fig. 8 mark all the trajectories having tropopause crossing times between 0 and 70 days and where GLORIA observations reveal a water vapor content of less than 3 ppmv. Indeed, there is a very good correla- 
a)

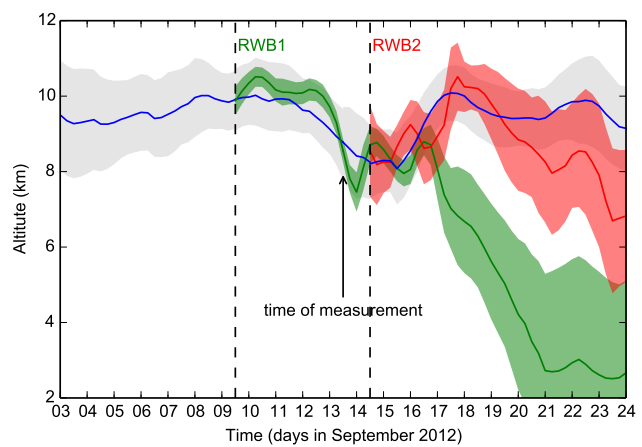

c)

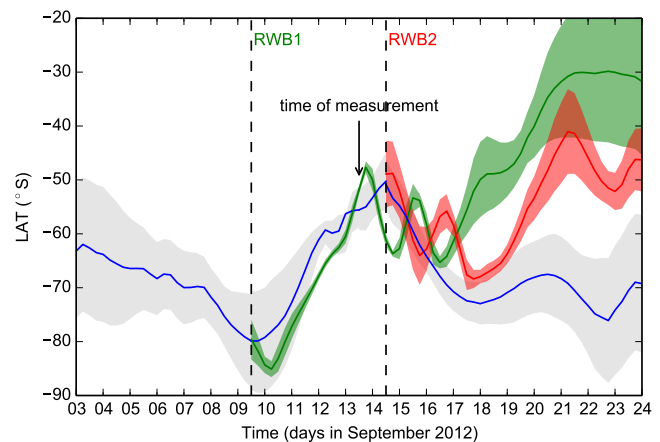

b)
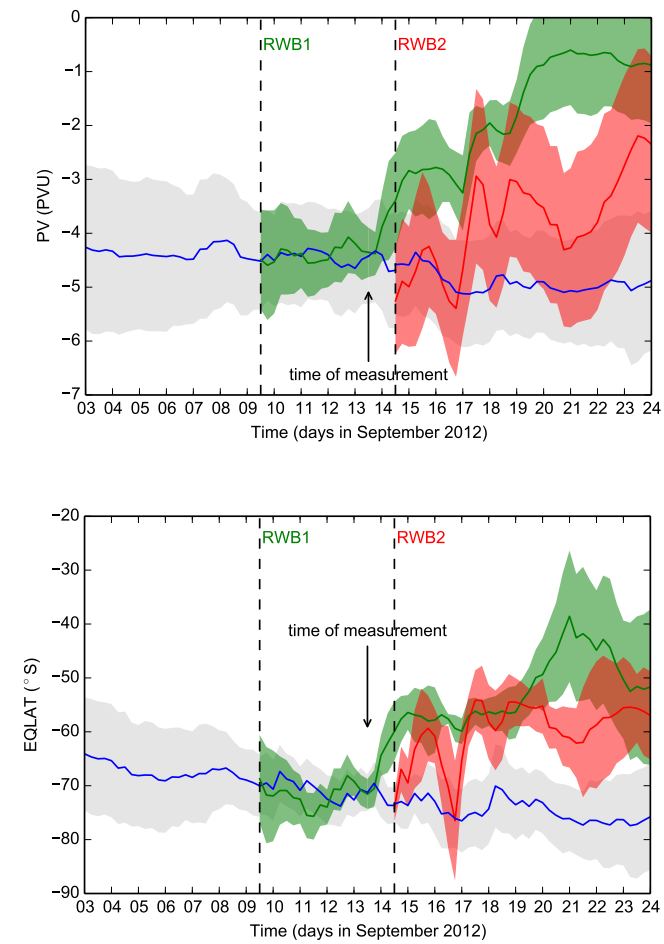

Figure 9. Air parcel properties based on trajectory analyses for all green-framed trajectories from Fig. 8 for the period of 2 weeks before to 2 weeks after the measurement. On 3 September the median of all 1400 trajectories is represented by the blue line with the respective standard deviation as gray shadow. At RWB event 1 a subset of 250 trajectories (green line, median) is separated from the rest (from that moment on the blue line represents 1150 trajectories). At RWB event 2 a subset of 200 trajectories (red line, median) is separated from the rest (from that moment on the blue line represents 950 trajectories): (a) median of potential temperature $(\theta)$, (b) median altitude above mean sea level, (c) median latitude, and (d) median equivalent latitude. The gray, green and red shaded areas marks the respective SD of the trajectories.

tion between the light-blue air masses, which crossed the thermal tropopause between 2 and 6 days before, and the green-framed areas marking the dehydrated air masses. In addition to the low water vapor content in the green-framed areas, higher values of ozone were also observed by GLORIA, which corroborates the stratospheric origin of these air masses (not shown here).

Figure 9 shows the median altitude (a), PV (b), latitude (c) and equivalent latitude (d) distributions of all trajectories within the green-framed areas from Fig. 8 for the period of 2 weeks preceding and the 2 weeks following the observation. In addition, two RWB events are marked where subsets of air masses (green and red line) are detached and separated from the rest (blue line). The strong Rossby wave activity is made visible by comparing the median latitude and equivalent latitude just a few days before the observation ( 8 to 17 September) as seen in Fig. 9c and d. The latitude is oscillating from near 70 down to $80^{\circ} \mathrm{S}$, up to $50^{\circ} \mathrm{S}$, and then back to $70^{\circ} \mathrm{S}$, while the equivalent latitude in this time frame stays constant at around $70^{\circ} \mathrm{S}$. This implies no PV change and only an isentropic latitudinal displacement due to planetary Rossby waves.
On 10 September, on the point furthest south at latitudes around $80^{\circ} \mathrm{S}$ (see Fig. 9c), the back trajectories split up into two different branches, indicating a bifurcation point caused by partly breaking the Rossby wave. Later, at the point of most northward displacement (around $50^{\circ} \mathrm{S}$ ) a second RWB event is identifiable; from then on, parts of the air masses are separated from the rest. The air masses associated with the first RWB event (green line) stay at a similar altitude and PV level for at least up to 14 September. At this day the PV starts to increase further to more tropospheric values, while the altitude starts to decrease later from 17 September on rapidly within 4 days to an altitude of less than $3 \mathrm{~km}$ with a simultaneous decrease in latitude to $30^{\circ} \mathrm{S}$. The previous PV change before the altitude change indicates the point in time where air masses detach the lowermost stratosphere and become more tropospheric. The trajectories associated with the second RWB event (red line) show a similar behavior but shifted by about 3 days. Thus it is not possible to match one specific event to the transport of all air masses which were observed below the thermal tropopause with low water vapor content (green-framed areas in Fig. 8). This implies that one Rossby wave event is not the sole reason for the 
downward transport. Parts of the air masses (950 trajectories) within the stratospheric intrusion did not leave the lowermost stratosphere within the 2 weeks. Indeed, if one looks into the following weeks, additional Rossby wave and RWB events occurred, bringing more parts of the remaining air masses (950 trajectories) into the troposphere.

Thus, RWB events drive the mixing process together with isentropic transport through the thermal tropopause. Additionally, RWB events detach air masses from the PV structure and can facilitate a wave-driven, secondary circulation that transports warmer air masses from around the vortex edge to the colder inner vortex. The change in PV is most likely not caused by cloud processes due to the dryness of these air masses. However, despite the dryness, the slight enhancement of ozone and the residual water vapor enable radiative cooling and a reduction in potential temperature, i.e., descent of air masses. Once transported into the troposphere, air masses will be transported down to near-surface level within few days as already suggested by Stohl and Sodemann (2010).

The vortex becomes more and more unstable during the Antarctic spring, and one may assume that this mixing event is already a first sign of the vortex break-up. Haigh and Roscoe (2009) reported about recent Antarctic final warming events occurring between the beginning of December and late January at the $100 \mathrm{hPa}$ level. Therefore, the observed inmixing of vortex air masses occurs long (at least 2 months) before the final warming and break-up of the vortex. It is therefore independent of the final warming event to a certain extent and seems to be a frequently occurring process in the Antarctic winter and spring.

Finally, the reason for the large downward transport is a mixture of strong Rossby wave activity, the presence of a permeable thermal tropopause, RWB events and the additional radiative cooling with corresponding subsidence of the air masses.

\section{Conclusions}

Detailed observations of dehydration and STE in the Antarctic UT/LS are very rare. In this study, we used highresolution in situ and remote sensing measurements taken from aboard the HALO aircraft in combination with an extensive trajectory case study to answer the following questions:

1. Can we confirm dehydration in the lowermost stratosphere and at the bottom of the Antarctic vortex? We observed strongly dehydrated air in the lower vortex at potential temperatures of 350 to $360 \mathrm{~K}(\approx 12-13 \mathrm{~km})$ with the hygrometers FISH and HAI. The final dehydration can be traced back to several ice formation events occurring at 350 to $370 \mathrm{~K}$, in a time frame of several weeks, where water is sedimented out of the observed air masses. Finally, dehydration occurs directly in the lower vortex and in the lowermost stratosphere below the vortex.

2. How deep do dehydrated air masses from the vortex descend into the troposphere? Dehydrated air masses are also observed with the high-resolution remote sensing instrument GLORIA down to the thermal tropopause, as well as below this point, down to $7 \mathrm{~km}$ in altitude. We confirm that dehydrated air masses with a water vapor mixing ratio $<3$ ppmv cover large regions of the Antarctic lowermost stratosphere down to the -2 PVU isoline and thus dominate at least for this observed case the transition region between the upper troposphere and lower stratosphere. But besides that, small filaments of enhanced water vapor are observed by GLORIA in the vortex air and the lowermost stratosphere at 330 to $350 \mathrm{~K}(\approx 10-12.5 \mathrm{~km})$. These filaments can be clearly assigned to in-mixing of moister air masses into the dry vortex at several points in time, indicating that this transport process occurs frequently.

3. Where and how have Antarctic dehydrated stratospheric air masses been transported? With an extensive trajectory case study, dry air masses below the thermal tropopause in the southern hemispheric polar and midlatitude region are determined to have stratospheric origin. The enhanced permeability of the Antarctic thermal tropopause in winter and spring allowing isentropic downward transport is confirmed (e.g., Zängl and Hoinka, 2001; Roscoe, 2004; Evtushevsky et al., 2011). It is shown that parts of these dry air masses are transported further down to near-surface levels within a few days. This transport into the troposphere is caused by several RWB events, where they detach air masses from the PV structure. Once the air masses have been transported into the Antarctic troposphere, most likely radiative cooling causes their subsidence to near-surface levels.

Acknowledgements. Sincere thanks go to the whole CLaMS team and in particular to Jens-Uwe Grooß for supporting the trajectory calculations. We acknowledge the NASA Langley Research Atmospheric Science Data Center for providing the CALIPSO data. In addition, we acknowledge the European Centre for Medium-Range Weather Forecasts for meteorological reanalysis data support. The development and application of the HAI instrument was financially supported by the German Science Foundation (DFG). We thank all members of the GLORIA instrument team for their great efforts in developing the first IR limb imager. The GLORIA hardware was mainly funded by the Helmholtz Association of German Research Centres through several large investment funds. Great thanks go to the coordinators of the TACTS campaign, Andreas Engel and Harald Bönisch, and of course to the whole HALO community for the great work during both campaigns. We thank Jens-Uwe Grooß for assisting the flight planning by CLaMS model forecasts 
supported by the German Research Foundation (DFG) through the project LASSO (HALO-SPP 1294/GR 3786). Special thanks go to Anna Luebke for language revision. Finally, we greatly acknowledge the two reviewers, Heini Wernli and Howard Roscoe, as well as Adrian Tuck, who provided constructive and fruitful comments leading to an improvement of the study.

The article processing charges for this open-access publication were covered by a Research

Centre of the Helmholtz Association.

Edited by: F. Khosrawi

\section{References}

Beuermann, R., Konopka, P., Brunner, D., Bujok, O., Günther, G., McKenna, D. S., Lelieveld, J., Müller, R., and Schiller, C.: Highresolution measurements and simulation of stratospheric and tropospheric intrusions in the vicinity of the polar jet stream, Geophys. Res. Lett., 29, 1577, doi:10.1029/2001GL014162, 2002.

Buchholz, B.: Entwicklung, Primärvalidierung und Feldeinsatz neuartiger, kalibrierungsfreier Laser-Hygrometer für Forschungsflugzeuge, Dissertation, Technische Universität Darmstadt, 2014.

Buchholz, B., Kühnreich, B., Smit, H. G. J., and Ebert, V.: Validation of an extractive, airborne, compact TDL spectrometer for atmospheric humidity sensing by blind intercomparison, Appl. Phys. B-Lasers O., 110, 249-262, doi:10.1007/s00340012-5143-1, 2013.

Buchholz, B., Böse, N., and Ebert, V.: Absolute validation of a diode laser hygrometer via intercomparison with the German national primary water vapor standard, Appl. Phys. B-Lasers O., 116, 883-899, doi:10.1007/s00340-014-5775-4, 2014.

Dee, D. P., Uppala, S. M., Simmons, A. J., Berrisford, P., Poli, P., Kobayashi, S., Andrae, U., Balmaseda, M. A., Balsamo, G., Bauer, P., Bechtold, P., Beljaars, A. C. M., van de Berg, L., Bidlot, J., Bormann, N., Delsol, C., Dragani, R., Fuentes, M., Geer, A. J., Haimberger, L., Healy, S. B., Hersbach, H., Holm, E. V., Isaksen, L., Kallberg, P., Koehler, M., Matricardi, M., McNally, A. P., Monge-Sanz, B. M., Morcrette, J.-J., Park, B.-K., Peubey, C., de Rosnay, P., Tavolato, C., Thepaut, J.N., and Vitart, F.: The ERA-Interim reanalysis: configuration and performance of the data assimilation system, Q. J. Roy. Meteor. Soc., 137, 553-597, doi:10.1002/qj.828, 2011.

Engel, A., Bönisch, H., and TACTS-Team: An overview on the TACTS mission using the new German research aircraft HALO in summer 2012, EGU General Assembly, Vienna, Austria, 7-12 April 2013, EGU2013-25 9191, 2013.

Ern, M., Preusse, P., Gille, J. C., Hepplewhite, C. L., Mlynczak, M. G., Russell III, J. M., and Riese, M.: Implications for atmospheric dynamics derived from global observations of gravity wave momentum flux in stratosphere and mesosphere, J. Geophys. Res., 116, D19107, doi:10.1029/2011JD015821, 2011.

Evtushevsky, O., Klekociuk, A., Grytsai, A., Milinevsky, G., and Lozitsky, V.: Troposphere and stratosphere influence on tropopause in the polar regions during win- ter and spring, Int. J. Remote Sens., 32, 3153-3164, doi:10.1080/01431161.2010.541515, 2011.

Friedl-Vallon, F., Gulde, T., Hase, F., Kleinert, A., Kulessa, T., Maucher, G., Neubert, T., Olschewski, F., Piesch, C., Preusse, P., Rongen, H., Sartorius, C., Schneider, H., Schönfeld, A., Tan, V., Bayer, N., Blank, J., Dapp, R., Ebersoldt, A., Fischer, H., Graf, F., Guggenmoser, T., Höpfner, M., Kaufmann, M., Kretschmer, E., Latzko, T., Nordmeyer, H., Oelhaf, H., Orphal, J., Riese, M., Schardt, G., Schillings, J., Sha, M. K., Suminska-Ebersoldt, O., and Ungermann, J.: Instrument concept of the imaging Fourier transform spectrometer GLORIA, Atmos. Meas. Tech., 7, 35653577, doi:10.5194/amt-7-3565-2014, 2014.

Giovanelli, G., Bortoli, D., Petritoli, A., Castelli, E., Kostadinov, I., Ravegnani, F., Redaelli, G., Volk, C. M., Cortesi, U., Bianchini, G., and Carli, B.: Stratospheric minor gas distribution over the Antarctic Peninsula during the APEGAIA campaign, Int. J. Remote Sens., 26, 3343-3360, doi:10.1080/01431160500076210, 2005.

Haigh, J. D. and Roscoe, H. K.: The final warming date of the Antarctic polar vortex and influences on its interannual variability, J. Climate, 22, 5809-5819, doi:10.1175/2009JCLI2865.1, 2009.

Hoffmann, L., Xue, X., and Alexander, M. J.: A global view of stratospheric gravity wave hotspots located with Atmospheric Infrared Sounder observations, J. Geophys. Res., 118, 416-434, doi:10.1029/2012JD018658, 2013.

Jimenez, C., Pumphrey, H. C., MacKenzie, I. A., Manney, G. L., Santee, M. L., Schwartz, M. J., Harwood, R. S., and Waters, J. W.: EOS MLS observations of dehydration in the 2004-2005 polar winters, Geophys. Res. Lett., 33, L16806, doi:10.1029/2006GL025926, 2006.

Kaufmann, M., Blank, J., Guggenmoser, T., Ungermann, J., Engel, A., Ern, M., Friedl-Vallon, F., Gerber, D., Grooß, J. U., Günther, G., Höpfner, M., Kleinert, A., Kretschmer, E., Latzko, Th., Maucher, G., Neubert, T., Nordmeyer, H., Oelhaf, H., Olschewski, F., Orphal, J., Preusse, P., Schlager, H., Schneider, H., Schuettemeyer, D., Stroh, F., Suminska-Ebersoldt, O., Vogel, B., Volk, M. C., Woiwode, W., and Riese, M.: Retrieval of three-dimensional small-scale structures in uppertropospheric/lower-stratospheric composition as measured by GLORIA, Atmos. Meas. Tech., 8, 81-95, doi:10.5194/amt-8-812015, 2015.

Kelly, K. K., Tuck, A. F., Murphy, D. M., Proffitt, M. H., Fahey, D. W., Jones, R. L., McKenna, D. S., Loewenstein, M., Podolske, J. R., Strahan, S. E., Ferry, G. V., Chan, K. R., Vedder, J. F., Gregory, G. L., Hypes, W. D., McCormick, M. P., Browell, E. V., and Heidt, L. E.: Dehydration in the lower Antarctic stratosphere during late winter and early spring, 1987, J. Geophys. Res., 94, 11317-11357, doi:10.1029/JD094iD09p11317, 1989.

Khaykin, S. M., Engel, I., Vömel, H., Formanyuk, I. M., Kivi, R., Korshunov, L. I., Krämer, M., Lykov, A. D., Meier, S., Naebert, T., Pitts, M. C., Santee, M. L., Spelten, N., Wienhold, F. G., Yushkov, V. A., and Peter, T.: Arctic stratospheric dehydration - Part 1: Unprecedented observation of vertical redistribution of water, Atmos. Chem. Phys., 13, 11503-11517, doi:10.5194/acp13-11503-2013, 2013.

Khosrawi, F., Müller, R., Beuermann, J., Konopka, P., and Schiller, C.: Dehydration in the Northern Hemisphere mid- 
latitude tropopause region observed during STREAM 1998, Tellus B, 58, 206-217, doi:10.1111/j.1600-0889.2006.00182.x, 2006.

Konopka, P., Günther, G., Müller, R., dos Santos, F. H. S., Schiller, C., Ravegnani, F., Ulanovsky, A., Schlager, H., Volk, C. M., Viciani, S., Pan, L. L., McKenna, D.-S., and Riese, M.: Contribution of mixing to upward transport across the tropical tropopause layer (TTL), Atmos. Chem. Phys., 7, 32853308, doi:10.5194/acp-7-3285-2007, 2007.

Krautstrunk, M. and Giez, A.: The transition from FALCON to HALO era airborne atmospheric research, in: Atmospheric Physics, edited by: Schumann, U., Springer Berlin Heidelberg, 609-624, 2012.

Lee, A. M., Jones, R. L., Kilbane-Dawe, I., and Pyle, J. A.: Diagnosing ozone loss in the extratropical lower stratosphere, J. Geophys. Res., 107, 4110, doi:10.1029/2001JD000538, 2002.

Mahowald, N. M., Plumb, R. A., Rasch, P. J., del Corral, J., Sassi, F., and Heres, W.: Stratospheric transport in a three-dimensional isentropic coordinate model, J. Geophys. Res., 107, ACH3.1ACH3.14, doi:10.1029/2001JD001313, 2002.

McKenna, D. S., Konopka, P., Grooß, J. U., Günther, G., Müller, R., Spang, R., Offermann, D., and Orsolini, Y.: A new Chemical Lagrangian Model of the Stratosphere (CLaMS) - 1. Formulation of advection and mixing, J. Geophys. Res., 107, 4309, doi:10.1029/2000JD000114, 2002.

Meyer, J., Rolf, C., Schiller, C., Rohs, S., Spelten, N., Afchine, A., Zöger, M., Sitnikov, N., Thornberry, T. D., Rollins, A. W., Bozóki, Z., Tátrai, D., Ebert, V., Kühnreich, B., Mackrodt, P., Möhler, O., Saathoff, H., Rosenlof, K. H., and Krämer, M.: Two decades of water vapor measurements with the FISH fluorescence hygrometer: a review, Atmos. Chem. Phys., 15, 85218538, doi:10.5194/acp-15-8521-2015, 2015.

Mihalikova, M. and Kirkwood, S.: Tropopause fold occurrence rates over the Antarctic station Troll $\left(72^{\circ} \mathrm{S}, 2.5^{\circ} \mathrm{E}\right)$, Ann. Geophys., 31, 591-598, doi:10.5194/angeo-31-591-2013, 2013.

Müller, R. and Peter, T.: The Numerical Modeling of the Sedimentation of Polar Stratospheric Cloud Particles, Berichte der BunsenGesellschaft-Physik Chemie, 96, 353-361, 1992.

Nash, E. R., Newman, P. A., Rosenfield, J. E., and Schoeberl, M. R.: An objective determination of the polar vortex using Ertel's potential vorticity, J. Geophys. Res., 101, 9471-9478, doi:10.1029/96JD00066, 1996.

Ndarana, T., Waugh, D. W., Polvani, L. M., Correa, G. J. P., and Gerber, E. P.: Antarctic ozone depletion and trends in tropopause Rossby wave breaking, Atmos. Sci. Lett., 13, 164168, doi:10.1002/asl.384, 2012.

Nedoluha, G. E., Bevilacqua, R. M., and Hoppel, K. W.: POAM III measurements of dehydration in the Antarctic and comparisons with the Arctic, J. Geophys. Res., 107, 8290, doi:10.1029/2001JD001184, 2002.

Nedoluha, G. E., Benson, C. M., Hoppel, K. W., Alfred, J., Bevilacqua, R. M., and Drdla, K.: Antarctic dehydration 1998-2003: Polar ozone and aerosol measurement III (POAM) measurements and integrated microphysics and aerosol chemistry on trajectories (IMPACT) results with four meteorological models, J. Geophys. Res., 112, D07305, doi:10.1029/2006JD007414, 2007.

Pitts, M. C., Poole, L. R., and Thomason, L. W.: CALIPSO polar stratospheric cloud observations: second-generation detection al- gorithm and composition discrimination, Atmos. Chem. Phys., 9, 7577-7589, doi:10.5194/acp-9-7577-2009, 2009.

Pitts, M. C., Poole, L. R., Dörnbrack, A., and Thomason, L. W.: The 2009-2010 Arctic polar stratospheric cloud season: a CALIPSO perspective, Atmos. Chem. Phys., 11, 2161-2177, doi:10.5194/acp-11-2161-2011, 2011.

Ploeger, F., Konopka, P., Günther, G., Grooß, J.-U., and Müller, R.: Impact of the vertical velocity scheme on modeling transport in the tropical tropopause layer, J. Geophys. Res., 115, D03301, doi:10.1029/2009JD012023, 2010.

Riese, M., Oelhaf, H., Preusse, P., Blank, J., Ern, M., FriedlVallon, F., Fischer, H., Guggenmoser, T., Höpfner, M., Hoor, P., Kaufmann, M., Orphal, J., Plöger, F., Spang, R., SuminskaEbersoldt, O., Ungermann, J., Vogel, B., and Woiwode, W.: Gimballed Limb Observer for Radiance Imaging of the Atmosphere (GLORIA) scientific objectives, Atmos. Meas. Tech., 7, 19151928, doi:10.5194/amt-7-1915-2014, 2014.

Pommrich, R., Müller, R., Grooß, J.-U., Konopka, P., Ploeger, F., Vogel, B., Tao, M., Hoppe, C. M., Günther, G., Spelten, N., Hoffmann, L., Pumphrey, H.-C., Viciani, S., D’Amato, F., Volk, C. M., Hoor, P., Schlager, H., and Riese, M.: Tropical troposphere to stratosphere transport of carbon monoxide and long-lived trace species in the Chemical Lagrangian Model of the Stratosphere (CLaMS), Geosci. Model Dev., 7, 2895-2916, doi:10.5194/gmd7-2895-2014, 2014.

Roscoe, H. K.: Possible descent across the "Tropopause" in Antarctic winter, Adv. Space Res., 33, 1048-1052, doi:10.1016/S02731177(03)00587-8, 2004.

Schiller, C., Bauer, R., Cairo, F., Deshler, T., Dornbrack, A., Elkins, J., Engel, A., Flentje, H., Larsen, N., Levin, I., Müller, M., Oltmans, S., Ovarlez, H., Ovarlez, J., Schreiner, J., Stroh, F., Voigt, C., and Vömel, H.: Dehydration in the Arctic stratosphere during the SOLVE/THESEO-2000 campaigns, J. Geophys. Res., 107, 8293, doi:10.1029/2001JD000463, 2002.

Schlager, H.: ESMval (Earth System Model Validation), available at: http://www.pa.op.dlr.de/ESMVal, last access: 18 July 2014.

Schoeberl, M. R. and Dessler, A. E.: Dehydration of the stratosphere, Atmos. Chem. Phys., 11, 8433-8446, doi:10.5194/acp11-8433-2011, 2011.

Schoeberl, M. R., Lait, L. R., Newman, P. A., and Rosenfield, J. E.: The structure of the polar vortex, J. Geophys. Res., 97, 78597882, 1992.

Škerlak, B., Sprenger, M., and Wernli, H.: A global climatology of stratosphere-troposphere exchange using the ERA-Interim data set from 1979 to 2011, Atmos. Chem. Phys., 14, 913-937, doi:10.5194/acp-14-913-2014, 2014.

Sprenger, M., Maspoli, M. C., and Wernli, H.: Tropopause folds and cross-tropopause exchange: A global investigation based upon ECMWF analyses for the time period March 2000 to February 2001, J. Geophys. Res., 108, 8518, doi:10.1029/2002JD002587, 2003.

Stohl, A. and Sodemann, H.: Characteristics of atmospheric transport into the Antarctic troposphere, J. Geophys. Res., 115, D02305, doi:10.1029/2009JD012536, 2010.

Tuck, A. F.: Synoptic and Chemical Evolution of the Antarctic Vortex In Late Winter and Early Spring 1987, J. Geophys. Res., 94, 11687-11737, 1989.

Tuck, A. F., Watson, R. T., Condon, E. P., Margitan, J. J., and Toon, O. B.: The planning and execution of ER-2 and DC-8 air- 
craft flights over Antarctica, August and September 1987, J. Geophys. Res., 94, 11181-11222, doi:10.1029/JD094iD09p11181, 1989.

Tuck, A. F., Brune, W. H., and Hipskind, R. S.: Airborne Southern Hemisphere Ozone Experiment Measurements for Assessing the Effects of Stratospheric Aircraft (ASHOE/MAESA): a road map, J. Geophys. Res., 102, 3901-3904, doi:10.1029/96JD02745, 1997a.

Tuck, A. F., Baumgardner, D., Chan, K. R., Dye, J. E., Elkins, J. W., Hovde, S. J., Kelly, K. K., Loewenstein, M., Margitan, J. J., May, R. D., Podolske, J. R., Proffitt, M. H., Rosenlof, K. H., Smith, W. L., Webster, C. R., and Wilson, J. C.: The BrewerDobson circulation in the light of high altitude in situ aircraft observations, Q. J. Roy. Meteorol. Soc., 123, 1-69, 1997 b.

Ungermann, J., Blank, J., Lotz, J., Leppkes, K., Hoffmann, L., Guggenmoser, T., Kaufmann, M., Preusse, P., Naumann, U., and Riese, M.: A 3-D tomographic retrieval approach with advection compensation for the air-borne limb-imager GLORIA, Atmos. Meas. Tech., 4, 2509-2529, doi:10.5194/amt-4-2509-2011, 2011.

Ungermann, J., Blank, J., Dick, M., Ebersoldt, A., Friedl-Vallon, F., Giez, A., Guggenmoser, T., Höpfner, M., Jurkat, T., Kaufmann, M., Kaufmann, S., Kleinert, A., Krämer, M., Latzko, T., Oelhaf, H., Olchewski, F., Preusse, P., Rolf, C., Schillings, J., Suminska-Ebersoldt, O., Tan, V., Thomas, N., Voigt, C., Zahn, A., Zöger, M., and Riese, M.: Level 2 processing for the imaging Fourier transform spectrometer GLORIA: derivation and validation of temperature and trace gas volume mixing ratios from calibrated dynamics mode spectra, Atmos. Meas. Tech., 8, 2473 2489, doi:10.5194/amt-8-2473-2015, 2015. van de Berg, W. J., van den Broeke, M. R., and van Meijgaard, E.: Heat budget of the East Antarctic lower atmosphere derived from a regional atmospheric climate model, J. Geophys. Res., 112, D23101, doi:10.1029/2007JD008613, 2007.

Vömel, H., Oltmans, S. J., Hofmann, D. J., Deshler, T., and Rosen, J. M.: The evolution of the dehydration in the Antarctic stratospheric vortex, J. Geophys. Res., 100, 13919-13926, doi:10.1029/95JD01000, 1995.

WMO (World Meteorological Organization): Meteorology ThreeDimensional Science: Second Session of the Commission for Aerology, WMO Bulletin IV(4), WMO, Geneva, 134-138, 1957.

Zahn, A., Weppner, J., Widmann, H., Schlote-Holubek, K., Burger, B., Kühner, T., and Franke, H.: A fast and precise chemiluminescence ozone detector for eddy flux and airborne application, Atmos. Meas. Tech., 5, 363-375, doi:10.5194/amt-5-3632012, 2012.

Zängl, G. and Hoinka, K. P.: The tropopause in the polar regions, J. Climate, 14, 3117-3139, 2001.

Zöger, M., Afchine, A., Eicke, N., Gerhards, M. T., Klein, E., McKenna, D. S., Morschel, U., Schmidt, U., Tan, V., Tuitjer, F., Woyke, T., and Schiller, C.: Fast in situ stratospheric hygrometers: A new family of balloon-borne and airborne Lyman alpha photofragment fluorescence hygrometers, J. Geophys. Res., 104, 1807-1816, doi:10.1029/1998JD100025, 1999. 